\title{
From Chávez to Maduro: Continuity and Change in Venezuelan Foreign Policy*
}

Carlos A. Romero(1) and Víctor M. Mijares(2)**

\section{Abstract}

This article addresses the transition from the presidency of Hugo Chávez to that of Nicolás Maduro, in the light of the effects of the dynamics in domestic politics and the changing international order on the formulation of Venezuela's foreign policy. We start from a central question: how does Maduro's government, amid a less favourable global scenario, face the international commitments made by its predecessor under complex and different domestic conditions? Our central hypothesis is that the historical currents of sociopolitical fragmentation, regional tensions and the energy market, pose difficulties to the continuation of an expansive foreign policy, but in turn act as a stimulus for greater centralisation of power internally, and the politicisation of the foreign policy agenda, in line with the objectives and general trends pursued by the governing party.

Keywords: Foreign Policy Analysis; Hugo Chávez; Nicolás Maduro; Venezuelan Foreign Policy; Bolivarian Revolution.

\footnotetext{
* Received on 16 October 2015 and approved for publication on 17 December 2015.

** (1) Universidad Central de Venezuela, Caracas, Venezuela. romecan53@ hotmail.com; (2) Universidad Simón Bolívar, Caracas, Venezuela, and German Institute of Global and Area Studies, Hamburg, Germany; vmijares@usb.ve.

*** Translated from Spanish to English by Luan Rocha Guerra.
} 


\section{Introduction}

Venezuelan foreign policy has been characterised by a growing dependency on oil market cycles. Although not a sufficient condition, a favourable oil scenario, with high prices and/or greater State capacity to capture income is a necessary condition for formulating ambitious objectives in Venezuelan foreign policy.

The interaction between this former feature and other domestic conditions, such as presidential charisma and legislative control by the governing party, have generated an important Venezuelan international activism. Three Venezuelan presidents have been known to project expansive doctrines of regional influence: the social democrats Rómulo Betancourt (1959-1964) and Carlos Andrés Pérez (1974-1979; 1989-1993), and the socialist Hugo Chávez (1999-2013). In contrast, and for reasons associated with the aforementioned conditions, each one of their successors (Raúl Leoni 1964-1969; Rafael Caldera 1969-1974 and 1994-1999, Luis Herrera Campins 1979-1984 and Nicolás Maduro 2013- ) has limited the scope of national objectives in international politics.

These shifts from a high intensity in foreign policy to periods of low intensity have exposed the changing conditions between each cycle. The continuity from Chávez to Maduro seems natural, since both leaders belong to the same party - the Partido Socialista Unido de Venezuela (PSUV) - the successor was anointed by the predecessor, and Maduro was, additionally, the longest-serving minister of foreign relations under Chávez. (Alarcón Deza 2014)

Nevertheless, many other factors have changed. Despite the President's ability to raise income without fiscal controls, the international oil market is averse to Venezuela since prices collapsed in June 2014. Maduro does not possess Chávez's charismatic personality traits and the regional environment has been narrowed by the reduction in the price of raw materials. How does Maduro's 
government deal with the compromises made by his predecessor under a less favourable international scenario and in complex domestic conditions?

This article analyses the effects that domestic political dynamics and the changing international order have had on the formulation of Venezuelan foreign policy, in the short time between the transition from Chávez to Maduro and the first years of the latter's mandate. Our central hypothesis is that the historic socio-political fragmentation streams, regional tensions and the energy market hinder the continuity of an expansive foreign policy, but in turn act as an important stimulus to greater internal power centralisation and to generating a conflictive and isolationist policy in the region.

This essay is divided into four sections: first, we expose our explicative model as a multi-level foreign policy analysis. In the second and third sections we present the domestic and international factors faced by the Venezuelan government and the diverse actors that in some manner affect the foreign policy and its politicisation, alongside the internal tensions. Finally, we present some conclusions and attempt to make short and mid-range predictions about the future of Venezuelan foreign relations.

\section{Foreign policy analysis model}

Foreign policy analysis has turned into an autonomous field of study within the international relations area. Its distinctive feature is indicated by the nature of the object, since analysis demands attention on two levels: domestic and international. The analysis of foreign policy leads to convergence between the political sub-disciplines of international relations and political systems (or comparative politics). 
Our analysis of Venezuela's recent foreign policy developments is non-exhaustively based on a model that combines elements from neoclassical realism (Rose 1998) and from rational choice theory (Glaser 2010), together with a neo-behaviourist (micropolitics) approach focused on the president as the main actor and on his answers to domestic and international environments (macropolitics) (Walker 2011).

Specialised literature has understood the considerable shift that has occurred in States' foreign policies and in international relations, practices and knowledge. This shift, boosted since the end of the Cold War, has led to a relative loss of academic interest in realism, the paradigm that dominated international studies for more than half a century. From this perspective, the power struggle between States and the lack of a global government generates a continuous political confrontation (Viroli 2009). Its most widely spread branch, the defensive (neo)realism, has among its conceptual bases the idea of exercising diplomacy with the aim of avoiding breaking the fragile balance of power in the international system, securing peace among great powers and channelling States' differences through negotiations, alliances and national power, and trying to avoid the use of force (Katzenstein 2010).

From a domestic perspective, realism presumes that government centralises foreign policy, which is one of the least socially accountable public policies, and the idea that national interest demands general consensus and therefore diplomacy - given its high secrecy and its value to national security - does not admit other than a limited internal debate (Lentner 2006).

Realism did not receive broad consensus within the field of international relations. From a juridical and military outlook, but also, subsequently, from an economic and psychological viewpoint, there were important reviews and criticisms of its analytical 


\section{From Chávez to Maduro: Continuity and \\ Change in Venezuelan Foreign Policy}

'amorality', its decision-making rationality limitations and its relationship with threats and use of power regarding the risks of military use of nuclear energy. It also received criticism regarding its disdain over the role of economy, commerce and economic inequality in the transformation of international structures, whilst interpreting national interest as something uniform, rejecting domestic relations as important sources of foreign policy aspects, concentrating its focus on nation-state behaviour as the fundamental actor for global dynamics (Glaser 2010).

Recently, there has been a series of new approaches that try to give new meaning to a variety of classic and (re)emerging themes such as multi-polarity, arms control (conventional and nuclear), security zones, hard and soft power, soft-balancing, 'bandwagoning', self-determination, weak states, humanitarian intervention, the public accountability of foreign policy and the role of the legislative power. We could not set aside the importance the Marxist and neo-marxist approaches have to this discussion, with their concepts of international asymmetry, imperialism, neo-colonialism, geo-culture, world-system, the role of peoples in international relations, the multi-polar world and, even more so, Weltanschauung, which have shaped a different analysis of globalisation, from a non-western perspective (Katzenstein 2010).

Despite resistance to change from central governments, the growth of post-national citizenship models and the multiplication of loyalties and identities give impulse to conforming transnational actors who move away from the notion of a compact national population. On the other hand, governments have had their functions limited by the global decisions and actions of multilateral bodies and of international organisations of a non-governmental character.

This is a very interesting phenomenon at a time when democratic theory presents the ideas of persuasion, accountability and 
participation as alternatives to coercion and the negotiation of particular interests, while democratic legitimacy, citizen participation channels on public decisions and institutional representation problems receive growing attention (Acemoglu and Robinson 2006; Viroli 2009).

Our explicative model assumes that the foreign policy of Chavista governments expresses a permanent contradiction between its efforts to decentralise international power and insert itself in critical and counter-hegemonic debates, and its tendency to concentrate domestic power and its legitimate authority to formulate, design and execute a foreign policy that denies participation possibilities to groups that could have different or opposite concrete interests and ideologies.

The model suggested to observe this case analyses the answers from a foreign policy executive (FPE) (Lobell 2009) that tends to centralise decisions in reduced debate spaces, while oriented to personalise the president's decisions - depending on his personality traits and effective power within the governing party - as well as his control over the oil industry and the armed forces. Charisma and perceptions play relevant roles in this model, as well as the effective and affective legitimacy achieved through electoral processes, but also with the (sympathetic and empathetic) identification of the political bases with the presidential figure. It is therefore about how ideational factors complement the material ones, usually referring to oil price control and its real available volume.

However, the image of the president as the only legitimate conductor of foreign relations is criticised by different and opposing streams and associations, including pro-government groups that aspire to participate in and form what they consider to be a revolutionary government. Thus, the model does not only interpret and explain the reactions of the FPE to its environment, but also the politicisation of 


\section{From Chávez to Maduro: Continuity and \\ Change in Venezuelan Foreign Policy}

foreign policy through its official promotion and the opposition's struggle to hold a dialogue with external actors.

\section{The domestic reality}

Since 1999, the Venezuelan government has unfolded a platform of international action that expresses itself on three interrelated levels: the actions of the Venezuelan state, including the role of Petróleos de Venezuela (PDVSA), the state controlled oil company; the role of the main official party, PSUV; and, President Chávez's - nowadays converted into a political myth (Blanco 2004; Serbín 2010) charismatic leadership.

Domestically, the Chávez and Maduro government's foreign policies have formed an organic part of their project and of the Venezuelan debate over its national destiny. Therefore, to identify Venezuela's role in international politics it is necessary to understand the duality of Venezuelan foreign policy. On the one hand, Venezuela is a State with international projection, whilst on the other hand it is a revolutionary State, sustained in the fortress built by oil resources (Romero 2006).

In fact, Bolivarian diplomacy has operated in a similar manner to that found in domestic issues, with a hegemonic project, the 21 st century socialism thesis and the 'ideological package' that includes the promotion of State-owned property, society's public control and indefinite presidential re-elections (Corrales and Romero 2014).

Caracas' relations with countries having non-liberal internal positions and economic tendencies to statism have been the priority, reflecting a diplomatic design that has contemplated not only the quest to reduce to a 'vital minimum' its dependence on the USA, but also the shaping of a power structure that aims to reflect a multi-polar and anti-capitalist world (Blanco 2004; Weyland 2009). 
The 1999 Constitution contemplates some social initiatives such as its concept of democracy, which is not the classical Western representative democracy present in the majority of Western constitutions, but rather a radical concept understood as the 'participative and leading democracy'. It is equally contemplated in the text of the Constitution that Venezuela is a multi-ethnic country that adopts the dual nationality principle (Romero et al. 2004).

Conversely, it is possible to submit international treaties, conventions and agreements that could compromise national sovereignty or transfer competencies to supranational organisations, to a referendum, either by popular initiative, or as arranged by the president, the ministers council, a two-third share of the Legislative chamber (National Assembly) or a fifteen percent share of registered voters in the Consejo Nacional Electoral (National Electoral Council) (Romero et al. 2004). Similarly, the Constitution is positively considered to be very progressive in human rights matters, as it grants constitutional dimension to international human rights treaties signed and ratified by Venezuela. The Constitution also contemplates and renews in articles 30 and 31 the right of Venezuelans to launch petitions to international human rights organisations, and forbids the extradition of national citizens (Romero et al. 2004).

Article 322 establishes that the nation's security and defence is the responsibility of the State, its natural population and its juridical people. The Bolivarian foreign policy constitutionally rests on the asymmetric war thesis, understood as the implementation of a social-military defensive policy responsive to any act judged as an aggression, considered as the co-responsibility of State and society to defend the country (Romero et al. 2004).

Venezuela's National Assembly is another public space where there is a relationship between both factors. Traditionally, it has been 
argued that parliaments in presidential systems have few powers regarding foreign policy matters. Nevertheless, in the past years it has been shown that they have some important functions. The Inter-Parliamentary Union and regional and national parliaments have an important political role when pronouncing on or supporting international cooperation between parliaments and its members (Serbin 2010).

There are many powers from the executive power that, in turn, should pass through legislative control: international treaties and conventions, international emergency and extraordinary powers to be granted to the executive branch, ambassadors' nomination procedures, authorisation for the President's travel, pronouncements on successful moves on the global chessboard, budgetary control of ministries and public powers consultation and co-responsibility. Furthermore, it is possible to highlight the agreements' applicability, the political pronouncements, the press releases and the debates carried out by the legislative power, as well as the role of members of parliament on foreign policy commissions. Other important activities include the nomination of ambassadors and the legislative support or rejection of the government's agreements, pronouncements and opinions.

From a constitutional point of view there is a formal relationship between foreign policy and society that emphasises some elements of direct democracy such as referenda, the constitutional principle of the multi-ethnic character of Venezuelan society, the constitutional status given to international treaties on human rights signed and ratified by Venezuela, and the right of citizens to petition directly to international human rights organisations. However, the constraints on defence and security issues and emergency measures, limit the constitutional relationship between the governing and the governed, as similarly occurs with the specific conditions within the Venezuelan parliament, where a pro-government majority, since 
1999, limited the impact the legislative power could have on foreign policy issues. In fact, this relative majority approved, without debate and without seeking consensus within the parliament, all the issues presented by the executive. In addition, on many occasions the Venezuelan parliament supported agreements favourable to certain diplomatic actions taken by Chavez's regime, whilst constitutional mechanisms of popular accountability and control envisaged in the text of the Constitution have been avoided (Serbin 2010).

After the strong victory of the Venezuelan opposition forces in the legislative election of December 2016, the control of the Venezuelan National Assembly by the Opposition representatives changed that kind of behaviour and opened the door to a more pluralistic debate and a greater legislative control of Venezuelan foreign policy.

On the other hand, the Chavista political direction has created the need to develop a hegemonic project with new bases in Venezuela, with a new political institutionalisation and a new narrative and iconographic content, including the foreign policy level and not concealing the desire to reduce to the minimum possible the ability of dissidents and critical sectors to act against the political majority (Corrales and Romero 2014). In this context, the relationship between government and society has been converted into an example of 'intermestic' politics to the extent that the Venezuelan government and its governing party (PSUV) have fomented international solidarity with global left-wing movements while accusing opponents of being instruments of foreign powers. The Chavista government's policy has included this solidarity as a crucial factor of political activism in Venezuela, counting on, officially, special cooperation from Cuba, above all with the developments regarding the Misiones Sociales (Social Missions), which have led to the presence of more than 35,000 Cubans in the country, working in professional areas and ideological instruction. It is also important to draw attention to the relevance that political and economic 
cooperation has for the Venezuelan regime, together with the expansion of Bolivarian socialism through known cooperation mechanisms such as ALBA and PetroCaribe, using oil resources as a political instrument (Cobo 2008).

From a different angle, other government entities, such as the ruling party and Venezuelan embassies, have promoted overseas a variety of solidarity programs, that range from a political endorsement and the financing of sympathisers, leaders, parties, non-governmental organisations and mass organisations' political activities to the financing of publications, Academic chairs, seminars and researches, as well as the promotion of cultural activities like those of the National Orchestras System, which in turn leads to external support of the government and the official party, PSUV (Cobo 2008).

Also of note is the role of the network of some publications in Venezuelan territory and abroad - such as national and regional radio station systems, community radio stations and public television channels, private and community, regional and national, as well as mandatory television broadcasts - in broadcasting international propaganda in favour of the Chavista regime. It is also important to acknowledge the foreign media that receives important support from Venezuelan government and officialdom and that has an impact on the public domestic debate, as happens with the international television channel Telesur, the printed magazine Le Monde Diplomatique and the online magazines and news programs 'Democracy Now!' and 'Venezuelanalysis' (Egaña 2009).

From the Venezuelan opposition's perspective, one can see how various institutions and the media, both foreign and national, have become the sound box for the conduct of the Venezuelan opposition: governments, parliaments, multilateral organisations, partner parties, opinion centres, mass media, professional congresses, 
political assemblies, universities, non-governmental and individual organisations, both abroad and inside the country's political life (Cobo 2008).

It is important to point up the role of the electoral alliances: the Polo Democrático in 1998, the Coordinadora Democrática (CD) between 2002 and 2005 and the Mesa de la Unidad Democrática (MUD) from 2010 onwards, where the respective international commissions dealt with foreign policy and international relations themes, including during presidential electoral campaigns. Another important moment was the international impact generated by the power vacuum (to some authors, a constitutional rupture or coup d'état) during Hugo Chávez's temporary withdrawal from the presidency in 2002, and the establishment of the Agreements and Negotiation Board between government and opposition in 2003. In preparing this initiative, the Carter Centre, together with OAS and UNDP, designed a peace development plan for Venezuela. This initiative also included the Group of Friends of the OAS Secretary General. On 29 May 2003 the agreement between the government and the Coordinadora Democrática (CD) was signed in order to bring about an electoral solution to the Venezuelan political crisis, through a referendum recall demand (Martínez Meucci 2012; Romero 2006).

We should also take in account the labour movement, the academic sectors, both national and foreign, specialised in Venezuelan studies, journalists, economic, electoral, diplomatic and international analysts, and also Venezuelan students and businessmen, as well such web portals as Twitter, YouTube, Instagram, Facebook and other social networks, all of which evaluate permanently national politics and Venezuelan foreign policy (Egaña 2009). Similarly, the activation of organisations of Venezuelan groups abroad (Cobo 2008; Blanco 2004; Morse 2012).

It is relevant to underline at this point the set back for the right of association and freedom of speech implied by the Popular Power 
Organic Law, the Social Comptroller Organic Law, the Political Sovereignty Defence Law and the National Self-determination Law, the Partial Reform Law on the Organic Telecommunications Law and the Social Responsibility Law on Radio, Television and Electronic Media, as well as other laws and regulations that by some means empower only socialist organisations to politically participate within the Venezuelan State and that discriminate those who are not in conformity with these political and ideological policies (Egaña 2009).

\section{The international panorama}

On the international stage, the USA and the People's Republic of China currently compete for world leadership in economic terms and, at a lower intensity, for military supremacy. Washington plays with Beijing's strategic containment, and intends to preserve its key alliances at minimal political cost. China, in the meantime, has used its economic capacities to strengthen the alignments among emerging powers (BRICS), to build a geopolitical block with a double but unequal Sino-Russian centre (Shanghai Cooperation Organisation), and to draw support from revisionist and revolutionary leaders in Africa and Latin America (Christensen 2015; Zhao 2015).

Emergent powers represent a second face of power diffusion. It is the case of 'monster-countries', using Kennan's expression, where developmentalist economies took advantage of the boom in the price of raw materials to force a converging or 'catching-up' effect with the world economy (Subramanian 2011). This tendency has opened up possibilities for new regional efforts, and also for foreign policies that have been reconfiguring the dynamics of regional security and defence policies. 
Latin-American and Caribbean governments are, at the moment stable. But drug trafficking and administrative corruption limit governability and public sector efficiency. Besides this, it is important to take into account the 'fatigue' experienced by the region, related to a lower rate of economic growth, the reduction in commerce with China, the lower levels of direct foreign investments and the increase in organised crime. Also important to highlight, and from a positive perspective, is the re-arrangement of Cuba-US relations, the progress of the peace negotiations between the Colombian government and the FARC, police and military control, the reduction in the level of criminal activities by terrorist groups, from drug traffickers and from social violence, and the promotion of democracy in the majority of the countries in the region.

The long diplomatic and intellectual South-American tradition to seek autonomy (Rivarola Puntigliano and Briceño-Ruiz 2013) has met favourable conditions in the current tendency towards a lower international concentration of power, as shown, to different degrees, by the efforts made by Brazil to consolidate a global presence, or the efforts made by Venezuela to develop a revolutionary foreign policy under Hugo Chávez's administration. At the regional level, the emergence of UNASUR, and in particular the endeavour of this regional organisation's Defence Council, may account for it.

Between the end of the 20th century and the beginning of the 21st we have witnessed the re-emergence of regionalism (Acharya 2014). In the specific framework of international security, the study of the regions has been treated from a structural approach (Lake and Morgan 1997; Buzan and Wæver 2003), based on the emergence of regional powers (Nolte 2010).

In this world of 'porous' regions framed by recent geopolitical and security tendencies in Latin America, one must address this particular international configuration to understand how Chavism's 


\section{From Chávez to Maduro: Continuity and \\ Change in Venezuelan Foreign Policy}

ideological materialisation was facilitated and how it articulated with Chávez's national strategy for Venezuela.

The low intensity of armed conflicts, post-Cold War, and the supposed lack of inter-State confrontations are the favourite arguments to refer to the region as a 'peace zone' (Hurrell 1998). Nonetheless, as demonstrated by David Mares (2001) and Félix Martín (2006), and also referred to by Jorge Battaglino (2012), the region, although far from experiencing the conflict levels of other places, is not a peace zone. The greatest difficulty faced by security studies of Latin America is how to deal with multi-dimensional threats (Diamint 2004). In the region, problems co-exist that range from the so-called 'maras' or gangs that have pushed the degree of violence to their limits in Central America, to traditional inter-State disputes, including the challenges represented by drugs production and trafficking, which together with judicial impunity explain why Latin America is the world's most violent continent in terms of homicides (Watts 2015).

Latin American geopolitics does not happen through parallels - as in Eurasia, the first area subject to geopolitical studies - but though meridians. And the international contact between its populations is limited to some 'live borders', where human interactions, commercial exchange and border conflicts are usually more frequent, and even coincide. But the most remarkable aspect is that Latin America is not, in the strict sense, a region, but a set of sub-systems: the Central-American/Caribbean, and the South American. These sub-systems, in their turn, present physical and cultural particularities, as in the case of the Mexican and the Central-American Isthmus republics and the Caribbean islands, where States with Hispanic, Francophone and Anglophone heritages co-exist. In South America, countries like Colombia and Venezuela consider themselves to be pivots between the Caribbean and the Andean worlds, while Guyana and Suriname are Caribbean and 
South American, with some Amazonian presence. South America is nowadays institutionally grouped at UNASUR, although the two main regional integration mechanisms in the region are split: MERCOSUR and the Pacific Alliance (that includes Mexico, a non-South American country).

Venezuela's foreign policy under Chávez contributed to deepening the geopolitical differences. The divide is not spatially perfect, as Ecuador is not part of the Pacific Alliance and Bolivia is about to become a full member of MERCOSUR. Despite this, both are members of a political mechanism promoted by Venezuela: ALBA, which modifies the balance vis-à-vis Brazil. The Pacific Alliance gathers emerging regional economies that perform under liberal principles, not only in economic terms, but also political. MERCOSUR economies, with the exception of Venezuela, work through inter-governmental cooperation aiming an opening and regulation of spaces for the private sectors, while in ALBA inter-governmental relations cover everything, largely because they are mainly State-run economies. The most recent available data reflects a strong correlation between the democracy (Polity IV Project 2013) and the economic freedom indexes (The Heritage Foundation 2015).

From a multi-dimensional threats panorama, together with differences regarding definitions and usages of political and economic liberties, it is natural that a variety of perspectives regarding threat awareness emerge. An example was the creation, around 2008-2009, of the Defence Council within UNASUR's framework. Initial proposals for the institutional design were associated with national objectives and the definition of threats. Thus, while the Venezuelan proposition was to create a collective defence alliance to dissuade the alleged hostile intentions of the United States, the Colombian proposition dismissed the possibility of such a Council. At the same time, while in Brazil the necessity for 
a deterrent mechanism arose as part of its plans to defend the Amazon and the 'Blue Amazon', in Argentina the thought was of strengthening its presence in the South Atlantic, and in Chile there was the wish to regulate and enhance the transparency of military procurement and expenditures. This last proposal turned out to be the only point of agreement among all countries (Mijares 2011; Mijares 2014a).

In this confusing environment, dominated by each government's interest in widening the national autonomy margins, emerged the Chavista Venezuela strategy, oriented towards a systemic change and stimulated by the combination of a disrupting ideology together with a high availability of, and capacity to deploy, resources.

Regional second-tier powers and petro-states like Venezuela, Iran, Malaysia, Kazakhstan or Nigeria, that could be considered geopolitical pivots more than geostrategic players, started to adopt more assertive foreign policies. Their foreign actions were aimed at undermining the foundations of US pre-eminence, trying to make multi-polarity irreversible and promoting their own systems of authoritarian government under electoral legitimacy schemes (Romero 2006; Morse 2012; Kneuer and Demmelhuber 2015).

In the Venezuelan case, high oil prices, able to generate important financing, the regional leadership with a political program of foreign projection, the effective control of the governing party and the reduction of the opposition's options, permitted a foreign policy of high ideological content and oriented to transforming the region (Romero 2006; Mijares 2015a). The revolutionary foreign policy changed Venezuela's alliance patterns, fomenting new regional schemes, and modifying the pre-existing regionalism. This policy demonstrated that under power diffusion conditions a secondary regional power with a driven leadership and an internal iron grip is 
capable of infringing the normative limits established under distinctive conditions of the international system.

The foreign policy objectives pursued by Venezuela during the successive presidencies of Chávez have tried to be explained form different angles. Our review of the different theses throws up three groups of non-exhaustive and partially compatible explanations: (i) the cognitive; (ii) the ideological; and (iii) the autonomists. The cognitive approaches have centred on the existence of an international status dissonance. Chávez's foreign policy would be, consequently, an attempt to establish a 'respectful' treatment that leans to the recognition of the regimes and of Venezuela's values and international status, mainly in face of great powers (Hermann 2015). The ideological explanations have detached aspects of a revolutionary foreign policy motivated by the transformation of the international system alongside socialist doctrinal principles (Romero 2006; Fürtig and Gratius 2010; Corrales and Romero 2013), although some of them have also considered the domestic function on the legitimacy process that this foreign policy performs (Corrales and Penfold 2011). On the other hand, the autonomist theses accentuate the aim to enlarge the margin of international operation, acting through power diffusion and promoting multi-polarity through new international blocs and renewed relations (Corrales and Romero 2013; Boersner and Haluani 2013).

The costs of cutting dependence on the US energy consumption market amid an oil boom era proved incompatible with the rest of the domestic and foreign objectives. The greatest paradox of the Bolivarian Revolution is that its main source of financing stems from Venezuela's commercial relations with the country that during Chávez's mandate was his nemesis. But the perception of the shifts on the international system led to a different oil trade policy. The rise of China is understood as an opportunity to diversify partners and markets for energy exports (Strecker Downs 2006). The progressive 
rearrangement policy that started in 2004 - with the oil boom and Chávez's consolidation that followed the recall referendum - saw Venezuelan crude oil start to flow in higher quantities towards Asia and a reduced flow towards North America (Mijares 2015b).

For the purposes of a regional projection with counter-hegemonic goals, the favourite instrument of the Chavista diplomacy was the alteration of the Inter-American institutional architecture. Constituting an 'authoritarian gravitational centre' (Kneuer and Demmelhuber 2015), Caracas served as a battering ram in the interests of breaking up the Free Trade Area of the Americas (FTAA) in 2005. Furthermore, it was the main promoter of the demolition of the hemispheric governance capability of the Organisation of American States (OAS). A similar conduct may be observed in the treatment received by the human rights theme in Venezuela, its opposition to the UN thesis of the 'right to protect', the crisis in the Arabic world, NATO's incursion into Libya, the pressures on Syria, its disagreement with the UN sanctions against Iran and Russia, the political treatment given to the United States, the Venezuelan prognosis of the $21^{\text {st }}$ century socialism, its differences in regard to the drug trafficking war and the guerrilla presence in Colombia. The South American geo-economic division also had Venezuela on its centre, with the shift from the second economy of the Andean Community towards MERCOSUR.

But Chávez's Venezuela was not limited to undermining the bases of hemispheric institutionalism or changing the patterns of regional association, and fostered the creation of a new institutional architecture with a clear objective to keep the United States out. This is how the enterprise of a southern military alliance articulates with the Brazilian proposal of a South American organisation that resulted in the creation of UNASUR and its Defence Council (Mijares 2011). Venezuela's last manoeuver was the Community of the Latin American and Caribbean States (CELAC, in Spanish), an 
initiative that lost impetus when faced by the neutralisation of interests made by two Latin American powers in potential rivalry: Brazil and Mexico.

One of the most striking actions taken on Venezuelan foreign policy relates to the agreements with the Russian State-run arms company Rosoboronexport (Boersner and Haluani 2013). The contract contributed to re-animate a largely neglected area of studies in South America: the military balance and strategic studies (Calle 2007; Battaglino 2008; Battaleme 2009). Faced with Washington's refusal to authorise the sale of highly sensitive materials to re-equip Venezuela - specially the sale of the Fighting Falcon F-16A air bombers - Caracas decided to replace its obsolete equipment with Russian aid. Therefore, for a period of five years, both countries signed 51 cooperation agreements, a credit line of US\$4 billion, contemplating the sale of 51 helicopters of the Mi series and 24 Sukhoi SU-30MK2 fourth generation fighter bombers, besides Kalashnikov rifles and the production of ammunition in the Venezuelan arms company CAVIM (Mijares 2011; Boersner and Haluani 2013). More than a disruption of an alleged technological-military dependence, what caught the attention was that military equipment renovation converted into a regional tendency that led some to call, with higher or lower precision, an 'arms race' in some cases, like that of Colombia and Venezuela (Calle 2007, Battaglino 2008, Battaleme 2009). Similarly, Venezuela and ALBA contributed to the Russian comeback as a military actor in Latin America and the Caribbean.

Another door opened by Venezuela to the entrance of extra-regional powers in Latin America was the financial one. The country's peculiarities in its own regional context - with its almost exclusively petrol-based economy - made it particularly sensitive to the reception of capital from a great (re)emerging power like China. By the third quarter of 2015, the estimation of Venezuelan's debt with 
China increased to more than US\$50 billion (Scharfenberg 2015). The guarantees of these credits connect with the already mentioned diversification and partial displacement of its energy policy, which reacts to the perception of a power transition on the international system. Through the energy route other credits and direct foreign investments have arrived in Venezuela, specially the projects in the Orinoco Belt, but also through civil engineering projects, in which Brazil has actively participated, along with China, Russia, Belarus and Iran. It demonstrates not only an interest in diversifying the societies, but also in the financial internationalisation beyond the Western Hemisphere. In other words, this is Venezuela's contribution to the world's multi-polarisation, even though at the expense of the interests of the region's main power: Brazil.

The last front, the diplomatic-global one, is in practice the framework where Venezuela's grand strategy under Chávez is inserted. The global diffusion of power, specially driven by the raw materials super-cycle, was perceived by the 'revolutionary government' as the opportunity to increase its international autonomy and preserve its own political regime with the lowest level of unwanted foreign intervention.

\section{From Chávez to Maduro: continuity and change in foreign policy}

The sequence of Chávez's presidencies: 1999-2000, 2001-2007 (interrupted for 36 hours in 2002) and 2007-2013, relied on different levels of stability and volume of earnings and, therefore, different moments of intensity in foreign policy. Thus, the most fruitful period of Chavez's foreign policy, the one where it gains its distinctive features, is between 2004 and 2009, amid the triumph of the recall referendum that occurred in Venezuela and the downfall of the Honduran President Manuel Zelaya, and during the raw materials 
boom. The domestic conditions of this Chavism 'golden age' are characterised by high levels of presidential popularity, with pre- and post-electoral shifts, and the legislative dominance of the PSUV, besides a slow opposition re-organisation process to structure the MUD. In the following graphic we present the evolution of Venezuelan democracy under Chávez. The first year, 1998, corresponds to Rafael Caldera's last year in presidency.

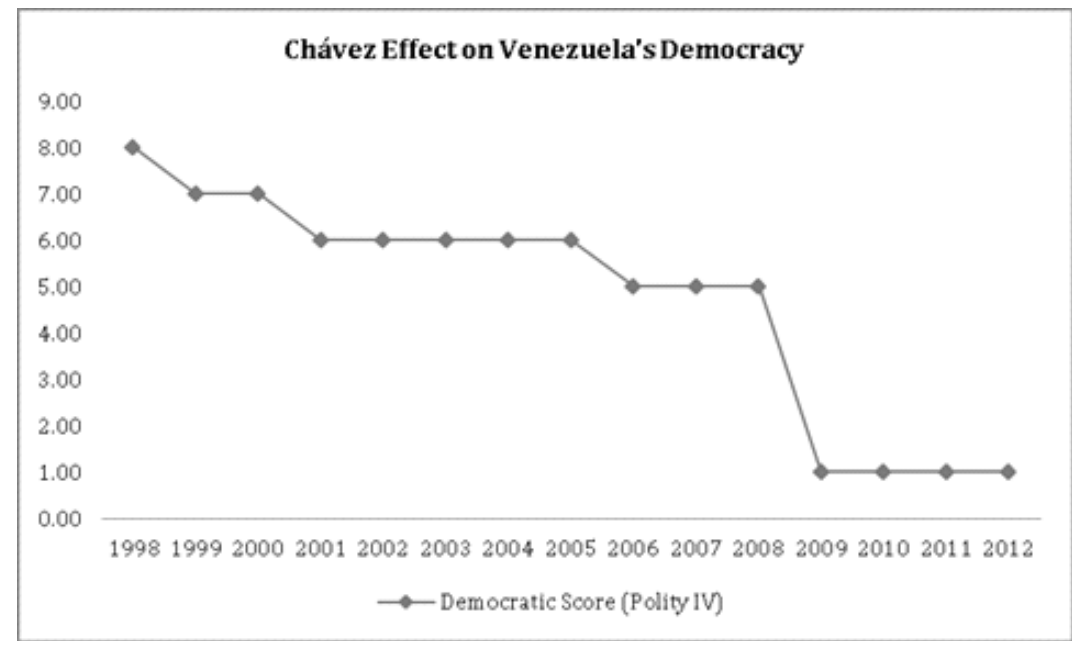

Graphic elaborated by the authors ${ }^{1}$

The data on the 'Chávez effect' over democracy bring questions to the generalized idea of Chavism radicalisation right after the events of April 2002. If we accept the data provided by Polity IV database, the promulgation of the 1999 Constitution had already generated an important damage on the Venezuelan democracy's quality, and the most severe deterioration would have been made obvious right after the combination of high oil incomes and greater legislative control permitted the 'colonisation' of the rest of the public powers.

This conduct led to a decline of the democratic quality of the Venezuelan political regime. However, it should not be forgotten 
that this process took place, largely, due to the Venezuelan opposition' erroneous political strategy of confronting the government, by all means possible. The main example was its refusal to participate in the 2005 legislative elections, which abandoned the totality of the National Assembly to Chavism, and facilitated the 'institutional dismantling' that put an end to the separation of powers and to checks and balances mechanisms in Venezuela. Since 2010, when MUD was created, a more rational and coherent strategy was adopted, which led to victories and progress that translated into - in the aftermath of the parliamentary elections of December 2015 - an opposition control of the National Assembly, giving space to a new democratic game in the country and a re-consideration of the role this new parliament could have in foreign policy matters.

Nicolás Maduro inherited from Chávez political control mechanisms that enable him to confront opposition parties without legal public funding, to enable a restrictive law over the media, and to count on the executive power's co-opted armed forces. These societal controls complement the broad powers that the Constitution already delegates to the President. This was the Venezuelan 'hyper-presidentialism' formula (Penfold 2010) that simplified the transition from Chávez to Maduro under conditions that violated the institutional channels. Regardless of these political advantages in face of the opposition sector, the President's greatest disadvantage was the control of the Chavista political movement itself. At a post-charismatic stage of low oil incomes, and lacking military experience, Maduro depends on a complex negotiation process and on a continuous re-arrangement within the Chavista alliance's inner forces, remaining as a primus inter pares within the highest hierarchy of power.

With reference to the international order, Chávez's presidency enjoyed extraordinary conditions associated with the power diffusion phenomenon: (1) the raw materials super-cycle; (2) the rise 
of (re)emerging powers; and (3) US geostrategic reorientation. High oil prices between 2003 and 2009 granted Chávez the opportunity to experiment with a regional foreign policy that was not completely new in the Venezuelan experience, though it had a 'revolutionary' ideological orientation. PetroCaribe was created with the intention of projecting the model promoted by Havana and Caracas. The rise of China, Russia and Brazil, but also of petro-states such as Algeria, Iraq, Iran, Libya and Syria, permitted a re-arrangement of foreign alliances and alignments, aiming at diversification. Finally, the US presence in two Eurasian operational theatres, Afghanistan and Iraq, as part of the 'War on Terror' doctrine, allowed a more defiant policy across the hemisphere, given the relatively low importance of Latin America in George W. Bush's foreign policy agenda.

The expansive and militant policy, conducted by Venezuela, cannot rest upon a favourable historical wind anymore. President Maduro not only had to deal with the end of the raw materials super-cycle, but also with the dramatic fall in oil prices - earning no empathy from its Arabic OPEC partners. Two of Venezuela's main economic and political partners, Brazil and Russia, are going through harsh socio-economic conditions, with a feeble government in Brasilia, and a regime in Moscow suffering the effects of sanctions imposed by Western power. China, for its part, continues to be the locomotive of the world's economy, despite having serious questions raised about its performance, which consequently brought progressive Yuan devaluations to compensate for the effect of disrupting distinctive domestic economic bubbles (Oehler-Sincai 2015).

Even more dramatic is the situation the allied Iraqi, Libyan and Syrian governments have faced. Chávez had already witnessed the judicial execution of Saddam Hussein, the extra-judicial execution of Gaddafi and the political marginalisation of President Bashar al-Assad. Maduro has not been able to maintain these alliances, and in friendly regimes there has been drastic changes in foreign policy, 
as in the Algerian introversion - due to President Bouteflika's health - , the switch of the Iranian government and the nuclear agreement reached with the P5+1 group (the USA, Russia, China, the UK, France and Germany). Changes in the regional ALBA allies still remain to be seen. Cuba, Venezuela's ideological reference, finds itself amid an ambitious overture process with the USA, and Ecuador and Bolivia have distanced themselves from the Venezuelan economic model, despite still offering political support to Caracas.

Analysing Washington's geo-strategic standpoint, the change is not favourable to Venezuela. President Barack Obama has proved to be more realistic in practice than in rhetoric (Ferguson 2015). When proposing to be the opposite version of his predecessor, he has made considerable efforts to limit the presence of US troops in Eurasia, to offer logistic but no tactical support on military intervention operations in the Middle East, and to reinforce the US naval presence on China's periphery under the 'Pivot to East Asia' policy. However, as opposed to what was expected, the geo-strategic contraction has not strengthened positions across the Western Hemisphere, and it seems to be part of a great strategy of political cost reduction and an efficient use of force. In Venezuela's case, the US government has committed itself to impose selective sanctions that ironically reinforced Maduro's position within Chavism, securing him stability in critical moments of his presidency.

In the light of the aforementioned international conditions, specially between 2003 and 2009, the projection of a socio-political and economic authoritarian centralisation model took place, and its expressed objective was the rupture of the international political order sustained in the Western Hemisphere, based on human rights, the free market and liberal democracy. The foreign autonomy is interpreted as a means and a purpose, through which the promotion of authoritarian political values, and alliances with similar regimes, are part of the same set of decisions and measures. Having said that, 
such revisionist doctrine requires huge surplus funds and a strong centralisation of internal political control, and its sustainment over time lacks guarantees in a changing international order, which is a bitter paradox for a disruptive and transforming policy. Its sustainability problems were quickly exposed with Chávez's death and Maduro's succession in 2013.

Venezuelan foreign policy under Chávez also carried out an internal legitimacy function, which pushed for a constant interaction with the international sphere. This created a paradoxical situation for his successor: Maduro states his legitimacy on the fidelity to the model inherited from his predecessor, and that includes the objectives and execution mechanisms of the country's foreign policy. But the domestic and international conditions, as we have already said, are different, making the continuity of the 'Chávez's doctrine' a toxic necessity for Maduro's foreign policy. Given this, the solution has been to assume a foreign policy that, without Chávez's maximalism, enables the revolutionary rhetoric to be sustained, but which in practice tends to reduce the crucial conflicts with the USA, narrows the oil diversification process, substituting it for a greater dependence on China, explores border conflicts with Guyana and Colombia, and points towards a partial insulation policy. 'Maduro's doctrine' is a survival from the Chavista political regime under adverse conditions, for it assumes a defensive configuration, instead of an offensive one, it retracts instead of being assertive, submitting itself to its real possibilities in a post-charismatic and falling oil incomes phase (Mijares 2015a).

\section{Conclusions}

The data analysed in relation to domestic and international policies allows us to widen our explicative model on the foreign policy of Chavista governments. They reveal that there is indeed a permanent contradiction, although in practice not dysfunctional, between its 
efforts to de-centralise international political power and insert itself in critical and counter-hegemonic debates, and its tendency to concentrate power and authority in foreign policy. The data suggests that, effectively, any possibility of participation is denied to groups that could attempt to show any different an ideological or concrete interest [from the official one].

In the proposed model the FPE tends to centralise the decisions in a few reduced spaces of debate, with a hyper-presidential orientation that also includes two bastions of power in Venezuela: the oil industry and the armed forces. As in the model, charisma and perceptions are as relevant as the effective and affective legitimacy through electoral processes, the re-arrangements within the popular support are strong foreign policy conditionings. They are the reason why ideational factors complement the material ones, usually referred to as the control of oil revenue and its real available volume. This foreign policy model faces the risk of entering a crisis cycle, given the continuous fall of oil prices since June 2014, the composition of the new National Assembly, controlled by a two-thirds opposition majority, an unprecedented counterbalancing event in contemporary Venezuela.

Thus, in the interaction between the model, the data and facts analysed it is possible to disclose that polarisation has been a central factor in the recent Venezuelan political dynamic, and that it has reflected the foreign policy design and the definition of national interest. Although being a natural dispute in every society, it is specifically problematic in Venezuela, where there is a strong and decided presidency, despite there being at the present time no legislative support. And there were very few occasions when government and opposition coincided over international and foreign policy themes, excepting some pronouncements where there was parliamentary consensus over global topics, as in the Venezuelan government's answer to Guyana's disagreement to proceed with negotiations over the Esequibo territory. Maduro's government 
nominated a presidential commission to negotiate the subject and an opposition bloc member from the National Assembly was included in it. This is, nonetheless, considered an extraordinary fact. It is expected that the differences will become more acute with the new National Assembly.

The social demands, far from ceasing, are embedded by distinct formal and informal mechanisms that have been created to offer stability to the government and continuity to the Revolution. But the strength of these mechanisms is connected to ideational, constitutional and material factors, being, respectively, charisma, the recognition of Venezuela as a multi-ethnic country and the public security measures offered by the State together with the performance of an extensively nationalised economy.

After 1999, as a result of the promulgation of the Constitution of the same year and of Chavez's foreign policy, a more substantial social participation in the formulation of Venezuelan foreign policy was expected. The politicisation of themes referred to the 'natives', 'the first folks', the 'Afro-Venezuelan' identity, the political and ideological accord with Cuba and other third-world countries and with left-wing movements from all around the world encouraged this expectation. However, the governments of President Chavez and now of Maduro have not allowed the development of this social dimension, this hypothesis being reinforced by the permanent exclusion of the opposition, and to a lesser extent, of pro-government social groupings in the decision-making processes, both in the formulation and execution of Venezuelan foreign policy (Alarcón Deza 2014).

If we follow Mandsfield and Snyder (2005) a scenario of re-democratisation is no guarantee of stability, especially with an open confrontation between public powers. The pressures for proportional representation questioned the essence of Chavez's foreign policy, and a greater politicisation of it could lead to instability in foreign relations. Border conflicts with Guyana and 
Colombia add up to probable casus belli scenarios or general mobilisations, specially in the theatre of operations of Esequibo, where asymmetry favours Venezuela. It is neither discarded internal confrontation, being a legitimating form in the face of radically opposed groups to an emerging order, or the implementation of staggering internal security policies, justified by the criminal violence that reigns over the country.

Venezuelan foreign policy will depend, though, on the direction that its government takes, and on the level that it will be counterbalanced by the opposition, now securing a parliamentary majority, as well as on how effective societal demands turn out to be. The first period of Maduro's government has shown critical episodes of violence and repression, and the persistence of its causes should not be underestimated to comprehend the Venezuelan political development (Mijares 2014b). Departing from two extreme values in regard to 'Chavism's strength' and a continuum about the political 'agreement-radicalism' variable, we composed a general two-by-two matrix with four scenarios that include the assignation of payments under rational assumptions of maximisation of potential rewards:

\begin{tabular}{c|l|l}
\hline & Strong Chavism & Weakened Chavism \\
\hline $\begin{array}{c}\text { Political } \\
\text { agreement }\end{array}$ & $\begin{array}{l}\text { (A) Revolutionary } \\
\text { institutionalisation: re-legitimated } \\
\text { Chavism and re-launching of an } \\
\text { expansive foreign policy with } \\
\text { opposition's representation. }\end{array}$ & $\begin{array}{l}\text { (B)Transition: governability pact } \\
\text { with consensual foreign policy }\end{array}$ \\
$\begin{array}{c}\text { Political } \\
\text { radicalism }\end{array}$ & $\begin{array}{l}\text { Payments Chavism/opposition: 2/1 } \\
\text { (C) Restoration: Chavism } \\
\text { re-legitimates itself and } \\
\text { re-launches an expansive and } \\
\text { centralised foreign policy. }\end{array}$ & $\begin{array}{l}\text { Payments Chavism/opposition: } 1 / 2 \\
\text { (D) Downfall: unilateral transition } \\
\text { and possible persecution of } \\
\text { Chavism, with a re-oriented foreign } \\
\text { policy centralisation }\end{array}$ \\
& $\begin{array}{l}\text { Payments Chavism/opposition: 3/0 } \\
\text { Payments Chavism/opposition: 0/3 }\end{array}$ \\
\hline
\end{tabular}

Table elaborated by the authors ${ }^{2}$ 
Quadrant (A) appears to be the least probable, since in a hypothetical restoration of Chavism's safeguard - that goes, among other factors, through an important and unexpected rise of oil prices - there are no discernible incentives to a political agreement. In reality, the payments matrices compared between (A) and (C), on the Chavism strengthening axis, show that the absolute and relative gains would lead to a radicalisation if the wind blows in favour of Maduro's government. Comparing the quadrants (B) and (D) could be more appealing to answer a more probable condition, that is, Chavism's weakening and the rise of the opposition. The most favourable payments matrix as a whole is the one represented in (B), as it could contribute to a new democratic pact in Venezuela.

Nevertheless, the most radical opposition forces could be tempted to 'exclude' Chavism if the opportunity emerges. This scenario would also radicalise Chavism, which would contemplate the realisation of its revolutionary meta-narrative, prompting a zero-sum game, the 'all or nothing' that was presented by the comparison between scenarios (C) and (D). In such a way, if radicalism prevails - a not so remote possibility - Venezuelan foreign policy would proceed to deepen the politicisation process that accompanies polarisation in the country, complicating and paralysing, at least partially, the revolutionary foreign agenda based on internal hegemony and high oil prices.

\section{References}

Acemoglu, Daron and James Robinson. 2006. Economic Origins of Dictatorship and Democracy. Cambridge: Cambridge University Press.

Alarcón Deza, Benigno (ed). 2014. El desafío venezolano: continuidad revolucionaria o transición democrática. Caracas: UCAB. 


\section{From Chávez to Maduro: Continuity and Change in Venezuelan Foreign Policy}

Alcañiz, Isabella and Timothy Hellwig. 2011. 'Who's to Blame? The Distribution of Responsibility in Developing Democracies'. British Journal of Political Science, 41(2): 389-411.

Acharya, Amitav. 2014. The End of American World Order. Cambridge: Polity.

Barbé, Esther. 2010. 'Multilateralismo. Adaptación a un mundo con potencias emergentes'. REDI LXII (2): 21-50.

Battaglino, Jorge M. 2008. 'Palabras mortales. Rearme y carrera armamentista en América del Sur?’ Nueva Sociedad 215: 23-34.

'The coexistence of peace and conflict in South America: toward a new conceptualization of types of peace'. Revista Brasileira de Política Internacional 55 (2): 131-151.

Battaleme, Juan. 2009. 'Releyendo la compra de armas en la región y la reintroducción del dilema de seguridad'. Miríada: Investigación en Ciencias Sociales 2 (4): 51-84.

Blanco, Carlos. 2004. Revolución y desilusión: la Venezuela de Hugo Chávez. Madrid: Catarata.

Bourse, Ana. 2014. 'La utopía post-westfaliana: tendencias y contramarchas globales, la gobernanza regional y el impacto sobre la sociedad civil en América Latina'. Pensamiento Propio 40: 284-320.

Bickerton, Emilie. 2015. 'La cultura después de Google'. New Left Review 92: 153-164.

Boersner, Adriana and Makram Haluani. 2013. 'Convergencias y divergencias en la asociación estratégica ruso-venezolana y sus implicaciones hemisféricas'. Cuadernos del CENDES 30 (82): 67-107.

Buzan, Barry and Ole WÆVER. 2003. Regions and Powers. The Structure of International Security. Cambridge: Cambridge University Press.

Calle, Fabián. 2007. 'Rambo, versión sudamericana. El impacto regional del rearme de Venezuela y Chile'. Nueva Sociedad 211: 13-21.

Cobo, Lourdes. 2008. Venezuela y el mundo transnacional: Instrumentación de la política exterior venezolana para imponer un modelo en América Latina. Caracas: ILDIS, CEERI. 


\section{Carlos A. Romero and Víctor M. Mijares}

Corrales, Javier and Michael Penfold. 2011. Dragon in the Tropics. Hugo Chávez and the Political Economy of Revolution in Venezuela. Washington D.C: Brookings Institution Press.

Corrales, Javier and Carlos Romero. 2013. U.S.-Venezuela Relations since the 1990s. New York: Routledge.

2014. 'Venezuela's Foreign Policy, 1920s-2010s'. In Jorge Dominguez and Ana Cobarrubias (eds). Routledge Handbook of Latin America in the World, New York: Routledge Press. pp. 153-168.

Christensen, Thomas J. 2015. 'Obama and Asia: Confronting the China Challenge'. Foreign Affairs 94 (5): 28-36.

Diamint, Rut. 2004. 'Security Challenges in Latin America'. Bulletin of Latin American Research 23(1): 43-62.

Dominguez, Jorge and Ana Cobarrubias (eds). 2014. Routledge Handbook of Latin America in the World. New York: Routledge Press.

Downs, Erica S. 2006. China's Quest for Energy Security. Santa Monica: RAND.

Egaña, Fernando. 2009. El Impacto de la Política Exterior en la Opinión Pública. Caracas: ILDIS.

Ferguson, Niall. 2015. 'The Meaning of Kissinger'. Foreign Affairs 94 (5): 134-143.

Fürtig, Henner and Susanne Gratius. 2010. 'Iran and Venezuela: Ideology-driven Foreign Policies in Comparison'. In Daniel Flemes (ed). Regional Leadership in the Global System. Ideas, Interests and Strategies of Regional Powers. Surrey: Ashgate. pp 169-190

Glaser, Charles L. 2010. Rational Theory of International Politics: The Logic of Competition and Cooperation. Princeton: Princeton University Press.

Heritage Foundation. 2015. '2015 Index of Economic Freedom' The Heritage Foundation. At http://www.heritage.org/index/explore. [Accessed on 1 August 2015]

Hermann, Isabella. 2015. 'Venezuela and the US: A Question of Status Misperceptions'. St Antony's International Review 10 (2): 117-140. 


\section{From Chávez to Maduro: Continuity and \\ Change in Venezuelan Foreign Policy}

Hurrell, Andrew. 1998. 'Security in Latin America'. International Affairs 74 (3): 529-546.

Katzenstein, Peter J. 2010. “'Walls' between 'Those People'? Contrasting Perspectives on World Politics'. Perspectives on Politics 8 (1): 11-25.

Kneuer, Marianne and Thomas Demmelhuber. 2015. 'Gravity centres of authoritarian rule: a conceptual approach'. Democratization, doi: 10.1080/13510347.2015.1018898.

Lake, David A and Patrick M Morgan. 1997. Regional Orders. Building Security in a New World. Pennsylvania: The Pennsylvania State University Press.

Lentner; Howard H. 2006. 'Public Policy and Foreign Policy. Divergences, Intersections, Exchange'. Review of Policy Research 22 (1): 169-181.

Linklater, Andrew. 2011. The Problem of Harm in World Politics. Theoretical Investigations. New York: Cambridge University Press.

Lobell, Steven E. 2009. 'Threat assessment, the state, and foreign policy: a neoclassical realist model'. In Steven Lobell, Norrin M Ripsman and Jeffrey W.Taliaferro (eds). Neoclassical Realism, the State, and Foreign Policy. Cambridge: Cambridge University Press. pp. 42-74.

Mansfield, Edward D and Jack Snyder. 2005. Electing to Fight. Why Emerging Democracies Go to War. Cambridge MA: MIT Press.

Mares, David R. 2001. Violent Peace. Militarized Interstate Bargaining in Latin America. New York: Columbia University Press.

Martín, Félix E. 2006. Militarist Peace in South America. Conditions for War and Peace. New York: Palgrave Macmillan.

Martínez Meucci, Miguel Ángel. 2012. Apaciguamiento: El Referéndum Revocatorio y la consolidación de la Revolución Bolivariana. Caracas: Editorial Alfa.

Mijares, Victor M. 2011. 'Consejo de Defensa Suramericano: obstáculos para una alianza operativa'. Politeia 34 (46): 1-46.

2014. 'The Paradoxical Effect of Multipolarity over the South American Security Governance'. In Peter Bátor and Robert Ondrejcsák (eds). Panorama 
of global and security environment 2014. Bratislava: Centre for European and North Atlantic Affairs. pp469-480.

2014 'Proteste in Venezuela und die Krise des Chavismus'. GIGA Focus Lateinamerika 2: 1-8.

2015. 'Venezuela's Post Chavez Foreign Policy. Is there a Maduro Doctrine?' Americas Quarterly 9 (1): 74-81.

2015. 'Crude juggling: Venezuela petro-strategy between U.S. and China'. Boletín del ISIAE 60: 34-39.

Morse, Yonatan L. 2012. 'The Era of Electoral Authoritarianism'. World Politics 64 (1): 161-198.

Nolte, Detlef. 2010. 'How to compare regional powers: analytical concepts and research topics'. Review of International Studies 36 (4): 881-901.

Nossel, Suzanne. 2004. 'Smart Power' Foreign Affairs 83 (2): 131-142.

Nye, Joseph S. 2009. 'Get Smart. Combining Hard and Soft Power'. Foreign Affairs 88 (4):160-163.

Oehler-Sincai, Iulia Monica. 2015. 'BRICS' Current Economic Situation: and Adaptative Phase?' Knowledge Horizons - Economics 7 (2): 41-45.

Penfold, Michael. 2010. 'La democracia subyugada: el hiperpresidencialismo venezolano'. Revista de Ciencia Política 30 (1): 21-40.

Polity Iv Project. 2013. 'Polity IV Database 2013'. Integrated Network for Societal Conflict Research (INSCR) Program, Center for International Development and Conflict Management (CIDCM), University of Maryland, College Park. At www.bsos.umd.edu/cidcm/inscr/polity. [Accessed on1 August 2015]

Rivarola Puntigliano, Andrés and José Briceño-Ruiz. 2013. Resilience of Regionalism in Latin America and the Caribbean: Development and Autonomy. New York: Palgrave Macmillan.

Romero, Carlos A. 2006. Jugando con el globo. La política exterior de Hugo Chávez. Caracas: Ediciones B.

Romero, Carlos A, María Teresa Romero and Elsa Cardozo Da Silva. 2004. 'La Política Exterior las Constituciones de 1961 y 1999: Una visión comparada de sus principios, procedimientos y temas'. In Luis Salamanca and Roberto 


\section{From Chávez to Maduro: Continuity and \\ Change in Venezuelan Foreign Policy}

Viciano Pastor (eds). El Sistema Político en la Constitución Bolivariana de Venezuela. Caracas: Centro de Estudios Políticos y Sociales, Vadell Hermanos, Instituto de Estudios Políticos de la Universidad Central de Venezuela. pp. 573-597.

Salamanca, Luis and Roberto Viciano Pastor (eds). 2004. 'El Sistema Político en la Constitución Bolivariana de Venezuela'. Caracas: Centro de Estudios Políticos y Sociales, Vadell Hermanos, Instituto de Estudios Políticos de la Universidad Central de Venezuela.

Serbin, Andrés. 2010. Chávez, Venezuela y la reconsideración política de América Latina y el Caribe. Buenos Aires: Siglo XXI Editora Iberoamericana, Plataforma Democrática.

Scharfenberg, Ewald. 2015. 'China presta 5.000 millones de dólares a Venezuela'. El País, 3 September. At http://internacional.elpais.com/ internacional/2015/09/03/actualidad/1441233476_308611.html. [Accessed on 29 September 2015]

Sharma, Shalendra D. 2010. 'Economic Governance in the Post-Crisis World: Balancing Regulation and Risk'. Yale Journal of International Affairs 5 (1): 100-111.

Subramanian, Arvind. 2011. Eclipse: Living in the Shadow of China's Economic Dominance. Washington D.C.: Institute of International Economics.

Viroli, Maurizio. 2009. De la Política a la Razón de Estado. Madrid: Ediciones Akal.

Walker, Stephen G. 2011. 'Foreign Policy Analysis and Behavioral International Relations'. In Stephen Walker, Akan Malici and Mark Schafer (eds). Rethinking Foreign Policy Analysis. States, Leaders, and the Microfoundations of Behavioral International Relations, pp 3-20. New York: Routledge

Watts, Jonathan. 2015. 'Latin America leads world on murder map, but key cities buck deadly trend'. The Guardian, 6 May. At <http://www.the guardian.com/world/2015/may/06/murder-map-latin-america-leads-world-ke y-cities-buck-deadly-trend>. [Accessed on 28 September 2015].

Weyland, Kurt. 2009. 'The Rise of Latin America's Two Lefts: Insights from Rentier State Theory'. Comparative Politics 41 (2): 45-164. 
Zhao, Suisheng. 2015. 'A New Model of Big Power Relations? China-US strategic rivalry and balance of power in the Asia-Pacific'. Journal of Contemporary China 24 (93): 377-397.

\section{NOTES}

1. Polity IV democratic score is obtained through consultation with experts and the aggregation of values on a scale of 11 points: $0-10$. The general attributes are: competitiveness to recruit to the executive power, overture in the recruitment, restrictions over the executive chief, participation regulation, and participation competitiveness. For further details please check the online Polity IV Dataset Users' Manual: http://www.systemicpeace.org/inscr/ p4manualv2013.pdf

2. The table exhibits a symmetric game that follows the logic of the game theory. Ordinal values of utility were assigned aiming to illustrate preference payments orders for each case. The values do not necessarily represent exact preferences, but are rather references to the payments. The numeric values correspond to qualitative criteria under the following notation: $0=$ Nothing; $1=$ Low; 2 =Average; 3 =High.

\section{About the Authors}

Carlos A. Romero is a Venezuelan political scientist who is expert on international relations and Venezuelan foreign policy. $\mathrm{He}$ is a Professor/Researcher Emeritus at the Institute of Political Studies and at the School of Political Studies of the Universidad Central de Venezuela. Carlos A. Romero has been a visiting professor in several academic institutions in Latin America, the United States and Western Europe. He has published six books and four in collaboration. His work has appeared in book chapters and numerous scholarly journals. His most recent co-authored book (with Javier Corrales) is US-Venezuela Relations since the 1990s (2013). His most recent article is Venezuela y Cuba: Los limites de un compromiso (2015). 


\section{From Chávez to Maduro: Continuity and \\ Change in Venezuelan Foreign Policy}

Víctor M. Mijares is Assistant Professor of Political Science (International Relations) at the Simon Bolivar University, Research Fellow at the German Institute of Global and Area Studies, and Ph.D. candidate in Political Science at the University of Hamburg. Areas of expertise: international security studies, international relations theory, and foreign policy analysis. Author of peer-reviewed papers and book chapters published by Revista de Ciencia Política, Politeia, Revista Venezolana de Análisis de Coyuntura, Centro de Estudios Políticos y Constitucionales, Publicaciones de la Universidad Católica Andrés Bello, and Centre for European and North Atlantic Affairs. Currently working on how power (de)concentration and global polarity affect regional security institutions, and on petro-states' foreign policy towards their own regions. 